\title{
Potential of brown algae for sustainable electricity production
}

\section{through anaerobic digestion}

\author{
Peyman Fasahati \\ Department of Biosystems and Agricultural Engineering, Michigan State University, East \\ Lansing, Michigan 48824, USA \\ Christopher M. Saffron \\ Department of Biosystems and Agricultural Engineering, Michigan State University, East \\ Lansing, Michigan 48824, USA \\ Hee Chul Woo \\ Department of Chemical Engineering, Pukyong National University, 365 Sinseon-ro, Nam-gu, \\ Busan 608-739, Korea

\section{J. Jay Liu*} \\ Department of Chemical Engineering, Pukyong National University, 365 Sinseon-ro, Nam-gu, \\ Busan 608-739, Korea
}

"Corresponding author. Department of Chemical Engineering, Pukyong National University, Busan, Korea, Tel: +82-51-629-6453, Fax: +82-51-629-6429, E-mail: jayliu@ pknu.ac.kr 


\begin{abstract}
This paper assesses the economics of heat and power production from the anaerobic digestion $(\mathrm{AD})$ of brown algae (Laminaria japonica) at a plant scale of 400,000 dry tons/year. The conversion process was simulated in Aspen Plus v.8.6 to obtain rigorous heat and material balance for energy assessments and the development of a techno-economic model. The breakeven electricity selling price (BESP) was found to be $18.81 \phi / \mathrm{kWh}$ assuming 30 years of plant life and a $10 \%$ internal rate of return. The results show that the AD unit has the highest energy demand in the entire process and consumes approximately $14 \%$ of all electricity produced. In addition, the seaweed cost of $11.95 \phi / \mathrm{kWh}$ is the largest cost component that contributes to the calculated BESP, which means that a reduction in the cost of seaweed cultivation can significantly decrease the electricity production cost. A sensitivity analysis was performed on the economic and process parameters in order to assess the impact of possible variations and uncertainties in these parameters. Results showed that solids loading, anaerobic digestion yield, and time, respectively, have the highest impact on BESP.
\end{abstract}

Keywords: Seaweed; Brown algae; Anaerobic digestion; Methane production; Electricity; Economic assessment. 


\section{Introduction}

Brown algae, as the third generation of biomass, has great potential as a renewable source of biomass for biofuel production. It requires no arable land, irrigation water, or fertilizer for cultivation, and has a higher photosynthetic efficiency of $6-8 \%$ compared to $1.8-2.2 \%$ for terrestrial biomass [1],[2]. The lack of lignin in the cell walls of brown algae makes the manufacturing process relatively simple compared to that for lignocellulosic biomass for which costly pretreatment processes are required to separate the cellulose from the lignin [3],[4].

The anaerobic digestion (AD) of biomass is biological decomposition of organic material to biogas by a mixture of microbes in the absence of oxygen [5]. The yield of the process is impacted by the type of digester selected, pretreatment process, hydraulic retention time (HRT), and source of inoculum [5],[7]-[9]. Generally, anaerobic digesters are categorized into batch vs. continuous process modes, mesophilic $\left(30-38{ }^{\circ} \mathrm{C}\right)$ vs. thermophilic $\left(49-57{ }^{\circ} \mathrm{C}\right)$ temperature conditions, high vs. low solids loading, and single stage vs. multistage processes [10],[11]. Several experimental, economic feasibility, and pilot-scale studies have shown the potential of using brown algae for methane production [5]-[9],[12],[13]. Rodriguez et al. [5] and Tedesco et al. [9] studied several pre-treatment techniques to improve the digestibility of seaweed for increased methane yield and reported that mechanical pretreatments results in higher methane yield in comparison to ultrasound and micro-wave, thermal, and chemical pretreatments. Some literature data show that brown algae can have an inhibitory impact on anaerobic digestion when it is considered for co-digestion with other types of biomass. Akunna and Hierholtzer [14] studied co-digestion of Laminaria digitate and green peas. Their results showed that when only $2 \%$ of feedstock of a reactor treating the green peas was replaced with the seaweed, methane production was disrupted and reactor stability was difficult to achieve thereafter. They concluded 
that certain seaweed constituents are inhibitory to the methanogens even at trace concentrations than to the other anaerobic digestion microbial groups. They recommended that appropriate adaptation strategy, involving initial low proportion of the seaweed relative to the total organic loading rate (OLR), and overall low OLR, is necessary to ensure effective adaptation of the microorganisms to the inhibitory constituents of seaweed. Sarker et al., [15] studied effect of variable feeding of Laminaria digitata for codigestion in a mesophilic and thermophilic digester with cattle manure. The study revealed that the variation in Laminaria feeding did not largely contribute to the average specific methane yield from the mesophilic co-digester. However, in thermophilic co-digester, seaweed addition enhanced the anaerobic digestion and boosted methane yield to a maximum of $39 \%$ at an average feeding rate of $24 \%$ VS of algae. Miura et al. [7],[8] evaluated marine sediments as a microbial source for methane production from brown algae at the salinity of seawater. They identified that acetoclastic methanogenesis is the ratelimiting step in brown algae anaerobic digestion and the batch-fed cultivation of microbes could better acclimate the culture to predominantly produce methanogens. In addition, AD under saline conditions implies that wet brown algae, containing approximately $80-90 \mathrm{wt} \%$ water, can be utilized directly. This can substantially reduce the fresh water requirements of the process and allow the biomass drying and washing steps to be bypassed.

In the United States (U.S.) in 1968, a feasibility study on marine biomass was conducted for making substitute natural gas ( $\mathrm{SNG}$ ) from marine biomass using anaerobic digestion (AD) as a conversion process [16]. Chynoweth reported the results of the program for the types and yield of seaweed cultivation farms, anaerobic digesters, and the potential for co-digestion with wastes [16]. Results showed that marine biomass was the least developed resource resulting in high gas cost estimates of 3-6 times those for U.S. natural gas. The program ended in 1990, because of 
low energy prices in the U.S. and reduced emphasis on renewable energy. However, in recent years, interest in marine biomass has been rekindled by the threat of global warming due to greenhouse gases (GHGs) from combusting non-fossil energy resources. In a study performed in 2005 at the Energy Research Centre of the Netherlands (ECN), Reith et al. [17] studied the economic feasibility of biofuels from offshore seaweed cultivation envisioned by 2020 in the North Sea using $1,000 \mathrm{~km}^{2}$ of offshore wind farm infrastructure. Their results showed, at a scale of 100,000 dry tons/year, that biomass price must be decreased by $75 \%$ to allow for economical electricity production from $\mathrm{AD}$ of seaweed. They concluded that a scale of 500,000 tons/year would be more appropriate for the commercial production of biofuels. In 2010, Roesijadi et al. [18] performed preliminary resource, economic, and environmental analyses based on the results obtained by Reith et al. to assess the potential of seaweed for biomethane production in the United States. They concluded that the methane yield of $0.124 \mathrm{~m}^{3} / \mathrm{kg}$ volatile solids (VS) considered by Reith et al. is very conservative compared to the yield of $0.22-0.30 \mathrm{~m}^{3} / \mathrm{kg}$ VS reported in the literature [19],[20] and, therefore, there are opportunities for improvement in the economics of methane from seaweed. Bruton et al. [21] also used the economic model of Reith et al. to evaluate the potential of aquatic biomass for biofuel production in Ireland. They concluded that the mass cultivation of seaweed should be prioritized to provide sufficient biomass to avoid the large-scale exploitation of wild seaweed stocks and its negative impact on supporting and maintaining marine biodiversity. In another study by Matsui et al. [10], a pilot plant at a scale of 1 ton/day was built in Japan for AD of drift seaweed, including Ulva and Laminaria species. The pilot plant operated successfully for over 150 days using two-stage $\mathrm{AD}$ and a mesophilic reactor temperature. The biogas was desulfurized and mixed with natural gas before use as fuel in a 
combined heat and power gas engine. The study showed that long-term and continuous operation of $\mathrm{AD}$ of seaweed is both possible and practical.

The production of electricity from brown algae has a high technology readiness level, based on the NASA (National Aeronautics and Space Administration) definition [22], considering the many $\mathrm{AD}$ trials with brown algae [5],[7]-[9], the numerous pilot plants installed, and that $\mathrm{AD}$ has been previously practiced for many other biomass varieties. However, there has not been an accurate and comprehensive techno-economic analysis of industrial-scale biomethane production using brown algae as biomass in the literature. This study fills this gap by performing a detailed economic assessment of electricity production using AD of brown algae considering recent achievements and technology advances in the field. With an increasing annual brown algae production rate [2] and determination of the global community to find sustainable and economical sources of energy to substitute fossil fuels and reduce GHG emissions, this study aims to provide a strong basis for decision- and policy makers to understand the potentials, limitations, and challenges of brown algae for renewable electricity production. For this purpose, a comprehensive literature study was performed to understand the current technology status. Later, the production process is rigorously simulated in Aspen Plus v.8.6 to close energy and material balances, which are then used to determine the process energy demands and to calculate the operating and capital costs that are quoted by specialized vendors. The calculated costs are used to develop a discounted cash flow analysis to calculate the breakeven electricity selling price (BESP) of the process. It is also the objective of this study to understand the bottlenecks and quantify the impact of the most sensitive parameters on the economics of the process. 


\section{Material and methods}

Brown algae L. japonica are the most cultivated type of seaweed with an annual world production of 5.998 million wet tons in 2013, having increased 1.8 million wet tons since 2000 [23]. Carbohydrates form approximately $60 \mathrm{wt} \%$ of dry mass and include laminaran $(\beta-1,3-$ linked glucan, $\left.\left(\mathrm{C}_{6} \mathrm{H}_{10} \mathrm{O}_{5}\right)_{n}\right)$; cellulose $\left(\beta(1,4)\right.$-linked D-glucose, $\left.\left(\mathrm{C}_{6} \mathrm{H}_{10} \mathrm{O}_{5}\right)_{\mathrm{n}}\right)$; mannitol (sugar alcohol, $\mathrm{C}_{6} \mathrm{H}_{14} \mathrm{O}_{6}$ ); alginate (an anionic polysaccharide composed of mannuronic and guluronic acids, $\left.\left(\mathrm{C}_{6} \mathrm{H}_{8} \mathrm{O}_{6}\right)_{\mathrm{n}}\right)$; and fucoidan (sulfated fucan) [15],[18]. Table S-1 of the supplementary data shows the chemical composition, elemental analyses, and heating value of L. japonica. Laminaria products are used for industrial, medical, human consumption purposes, and as livestock fodder. The main industrial products extracted from Laminaria are iodine, algin, and mannitol [1],[24]. Iodine is used as an additive to salt and other foods to prevent thyroid gland disorders and goiters. Algin is a hydrocolloid or phycocolloid made from extracted alginate or alginic acid that has the property of holding water in suspension. It is widely used as a binding agent in textile, printing, medical and food manufacturing industries. Mannitol is widely used in food and medical industries because of its medicinal properties. L. japonica contains approximately $88 \mathrm{wt} \%$ water in its wet form and $12 \mathrm{wt} \%$ total solids, of which $74 \mathrm{wt} \%$ are VS and $26 \mathrm{wt} \%$ is ash [15]. The high water $(>80 \%)$ and ash content ( 26\% dry wt) of brown seaweed make it challenging for thermochemical pathways, like gasification and pyrolysis [25], but more appropriate for biochemical pathways, like AD and fermentation processes [18],[26]. Generally, thermochemical pathways require biomass to be dried below $7 \%$ moisture content. This would require external source of heat since high heating value of seaweeds are relatively smaller than the one for lignocellulosic biomass [25]. In addition, high metal content of seaweeds compared to lignocellulosic biomass can potentially poison the bio-oil hydrotreating catalyst 
obtained from pyrolysis process [27]. Okoli et al. [25] studied the economics of butanol production from Laminaria japonica through gasification process. Their results showed that energy efficiency of a gasification process for brown algae to butanol process is about $12 \%$ less than the similar process for lignocellulosic biomass mainly because of higher ash content in brown algae. In addition, the minimum fuel selling price calculated for gasification of brown algae was about 2-3 times more than the MFSP calculated for a similar thermochemical and biochemical process using lignocellulosic biomass [25],[28]. Fig. 1 shows a simplified process flow diagram for electricity production from brown algae. The conversion process include an AD unit, boiler/turbogenerator, and utilities. A detailed process flow diagram (PFD), together with the energy and material balances, are provided in the supplementary data (Figs. S-1-6 and Table S-2-4).

$<$ Fig. 1. Simplified process flow diagram (PFD) of the electricity production through anaerobic digestion.>

\section{$2.1 \quad$ Process description}

\subsubsection{Anaerobic digestion}

In this study, an approach similar to the National Renewable Energy Laboratory (NREL) was considered for biomass delivery and specifications. In NREL's model [3], biomass is assumed to be delivered according to the specifications described in the Idaho National Laboratory (INL) design report for a pioneer uniform-format feedstock supply system [29]. In that design, biomass is stored in a central depot and is preprocessed and homogenized to a degree before delivery, such that the biorefinery receives feedstock with known, uniform-format specifications including particle size distribution, moisture content, and bulk density [3]. The

costs associated with biomass pretreatment and supply are assumed to be included in the biomass 
purchase price. It was assumed that biomass received at the plant gates contains approximately $20 \mathrm{wt} \%$ water. In this study, brown algae, L. japonica, is fed to the AD unit at a scale of 400,000 dry tons/year. An average yield of $0.265 \mathrm{~m}^{3} / \mathrm{kg}$ VS at $35{ }^{\circ} \mathrm{C}$, and 10 days HRT was assumed in this study. This average yield is between the minimum and maximum yield of $0.23-0.30 \mathrm{~m}^{3} / \mathrm{kg}$ VS reported by Chynoweth et al. [19] and Gunaseelan [20]. Table 1 shows the average yield and operating conditions reported in the literature for $\mathrm{AD}$ of several types of brown algae. Fasahati and Liu [30] performed a literature survey on $\mathrm{AD}$ of carbohydrates, lipids, and proteins in brown algae. They obtained and reported the stoichiometric reactions and conversions for volatile fatty acid production from carbohydrates [31],[32], and methane production from lipid [3], protein [33], and volatile fatty acids [34], which are utilized in this study. These stoichiometric reactions are shown in Table 2. An 85\% conversion of carbohydrates (excluding alginate) and 70\% conversion of proteins and lipids was assumed. To obtain the base yield of $0.265 \mathrm{~m}^{3} / \mathrm{kg}$ VS, an alginate conversion of $54.6 \%$ was back calculated.

Fresh water is heated by the exit vapors from the turbines in the turbogenerator unit and then added to the dry L. japonica to reach a solids loading ratio of $10 \mathrm{wt} \%$ prior to entering the anaerobic digesters. Chilled water is used to keep the anaerobic digestion temperature constant at $35^{\circ} \mathrm{C}$. The main vapor products of $\mathrm{AD}$ are $\mathrm{CH}_{4}, \mathrm{CO}_{2}, \mathrm{H}_{2}$, and $\mathrm{H}_{2} \mathrm{O}$ with a concentration of 27.5, $38.2,26.3$, and $5.3 \mathrm{~mol} \%$, respectively. The biogas is pressurized through a blower and is sent to a gas storage drum. The agitation power requirements of anaerobic digesters are estimated from [4] as $19.7 \mathrm{~W} / \mathrm{m}^{3}$ of the input feed to the reactors. A pressure filter separates the solid and liquid residues of the anaerobic digestion process. The pressed stillage water is considered wastewater. However, the solid residues (digestate) are rich in nutrients, such as nitrate and phosphate, and can be sold as fertilizer [35],[36]. Therefore, approximately $20 \mathrm{wt} \%$ of the solid residues is 
recycled in the anaerobic digesters as sources of inoculum and nutrients, while the rest become a coproduct of the plant.

$<$ Table 1. Reported operating conditions and methane yield for anaerobic digestion of several types of brown algae.>

<Table 2. Stoichiometric anaerobic digestion reactions obtained from literature [30].>

\subsubsection{Burner, boiler, and turbogenerator unit}

The burner, boiler, and turbogenerator unit designs and assumptions are based on the designs of the National Renewable Energy Laboratory (NREL) [3]. The biogas and fresh air are combined with pressurized air from the solid-liquid separator in the anaerobic digestion unit, passed through a blower, preheated by flue gases, and introduced to the burner. The combustor provides 98.4 million $\mathrm{kcal} / \mathrm{h}$ heat at $870{ }^{\circ} \mathrm{C}$ of which approximately $6.6 \%$ is assumed to be wasted. The flow rate of fresh air is manipulated to sustain an oxygen ratio of $1 / 6$ between the output and the input of the burner. Flue gases from the combustor at $278{ }^{\circ} \mathrm{C}$ are used to preheat the feed to the combustor and reach a $157^{\circ} \mathrm{C}$ outlet temperature. The concentration of $\mathrm{SO}_{2}$ in the flue gas is approximately 970 ppmw and requires a flue gas desulfurizer (FGD) in order to meet the standards for environmental emissions [42]. Inside the FGD, a $20 \mathrm{wt} \%$ lime slurry (calcium hydroxide) is sprayed at $20 \%$ stoichiometric excess. The FGD converts $92 \%$ of the incoming $\mathrm{SO}_{2}$ into calcium sulfate, which falls through the bottom of the spray dryer. The water in the slurry is vaporized and exits with the flue gas as exhaust through a stack.

The boiler package includes a water softener to remove minerals like calcium and magnesium, a deaerator to strip non-condensable gases from the makeup and condensate water, surge tanks, and pumps. Makeup water is preheated by vapors from the last stage of the turbogenerator and boiler blowdown. Then, together with the condensate, are treated and 
deaerated to produce the boiler feed water BFW. Oxygen in the BFW can pit the surfaces in the boiler. Therefore, an amine injection system is utilized for oxygen removal. BFW pumps increase the water pressure to $62 \mathrm{~atm}$, and then the $\mathrm{BFW}$ is preheated with steam to $177^{\circ} \mathrm{C}$. Scale formation inside the steam drum is inhibited by adding phosphate to the BFW. In addition, ammonia is added to neutralize the $\mathrm{pH}$ of hot condensate stream and avoid the corrosion of metal pipes and equipment. A boiler blowdown of $3 \%$ was assumed which is used to heat up the makeup water and then depressurized to atmospheric pressure. the liquid stream is pumped to wastewater treatment and the vapor is released to the air.

The turbogenerator system includes a three-stage turbine with two extraction ports. The exit vapors from last stage are collected in a final condenser. Approximately $13 \%$ of the superheated steam from the boiler is extracted from first extraction point of the turbine at $268{ }^{\circ} \mathrm{C}$ and 13 atm to feed the BFW economizer. An additional $7 \%$ is extracted at 9.5 atm and $233{ }^{\circ} \mathrm{C}$ and is used in the deaerator. The rest of the steam is condensed at 0.1 atm and is pumped back into the boiler. The turbine shaft turns a generator to produce electricity. The generator efficiency is assumed to be $85 \%$. The generator produces $35.8 \mathrm{MW}$ of power, of which approximately 7.3 MW is used by the process, leaving 28.5 MW to be sold to the grid.

\subsubsection{Utilities}

The utilities unit tracks the plant's usage of cooling water, chilled water, process water, and electricity. The PFD for this unit is shown in Fig. S-6 in the supplementary data. The process water manifold provides water at a constant pressure to the anaerobic digestion unit, boiler and cooling tower makeup, and the lime slurry for the FGD. The cooling tower and chilled water system is similar to the one reported in [3] and is designed to meet the cooling demands of the

process. The cooling tower system supplies cold water at $28{ }^{\circ} \mathrm{C}$ and allows for $9{ }^{\circ} \mathrm{C}$ temperature 
rise in heat exchangers. The evaporation rate of cooling towers is calculated by Aspen Plus for a temperature drop from $37{ }^{\circ} \mathrm{C}$ to $28{ }^{\circ} \mathrm{C}$. Part of the water in the cooling towers is lost through blowdown and windage. A windage and blowdown value of $0.005 \%$ of the total flow to the tower and $0.15 \%$ of the water leaving the tower basin is assumed, respectively. The chilled water system provides water at $4{ }^{\circ} \mathrm{C}$ and a return temperature of $15{ }^{\circ} \mathrm{C}$ using centrifugal chillers. A power requirement of $0.56 \mathrm{~kW} / \mathrm{ton}$ of refrigeration was estimated for the chiller compressor based on [4]. The cooling water requirement of the chiller system was considered to be equal to the heat removed in the chilled water loop.

\subsection{Process simulation}

The conversion process was simulated in Aspen Plus v.8.6 (Aspen Tech, Cambridge MA) at a scale of 400,000 dry tons/year. The non-ideal behavior of the liquid phase was modeled using the non-random two-liquid (NRTL) thermodynamic/activity model. The chemical composition of brown algae presented in Table S-1 in supplementary data was used as the biomass composition. Most of the components were available in the Aspen Plus data banks. However, components that were not available in the library were modeled according to the National Renewable Energy Laboratory's (NREL) physical property database developed for bioethanol from lignocellulosic biomass [3]. The component properties considered for the brown algae, L. japonica, have been reported previously by Fasahati et al. [26]. Hydrogen, oxygen, nitrogen, carbon dioxide, and methane are defined as Henry components in the simulation in order to calculate the solubility of these components in the water. Centrifugal pumps were modeled in the simulation considering an efficiency of $80 \%$. Anaerobic digesters were modeled using the RStoic block model. The air compressors in the pressure filter were modeled with an 
isentropic efficiency of 0.72 , and the turbines were modeled with an isentropic and mechanical efficiency of 0.85 and 0.96 , respectively [3].

\subsection{Heat integration}

Heat integration analyses is required to minimize the total utility requirements of the process. The process structure is relatively simple; therefore, not many scenarios were available for heat integration analysis. During the analysis, minimum temperature differences (MTD) of 10 ${ }^{\circ} \mathrm{C}$ and $5{ }^{\circ} \mathrm{C}$ were imposed for the heat-transfer between liquid-liquid and liquid-condensing vapor, respectively [43],[44]. Hot and cold streams were matched by prioritizing the matches between physically near streams and in the same plant location. Most of the heat was recovered by process-to-process heat integration. Figs. S-1-6 in the supplementary data show the PFD of the process in which heat transfer matches are shown. Once the process-to-process heat transfers were matched, the remaining amount of energy transfer was met by using appropriate utilities. For cooling demands above $40{ }^{\circ} \mathrm{C}$, cooling water at $28-37{ }^{\circ} \mathrm{C}$ was used. Chilled water at $4-15{ }^{\circ} \mathrm{C}$ operating condition was used to maintain the temperature constant at $35{ }^{\circ} \mathrm{C}$ in the anaerobic digesters. The only point where the process could not recover the heat was in the exit vapors from the turbines, where only part of the heat was recovered by heating fresh water for the anaerobic digesters and BFW production. Cooling water was used to condense any remaining vapors. The process itself did not have heating demands, except for the thermophilic anaerobic digestion case, which is assessed in the sensitivity analysis in Section 3.4.2. In that case, part of the steam was extracted from the turbogenerator at $233{ }^{\circ} \mathrm{C}$ and $10 \mathrm{~atm}$ to provide the heating demands. 


\subsection{Techno-economic model}

A techno-economic model was developed to evaluate the economics of the process. Most of the techno-economic model parameters assumed in this work are similar to the one considerd by the NREL for bioethanol production from corn stover [3],[4]. The techno-economic model is based on $n^{\text {th }}$-plant economic assumptions, meaning that several plants using the same technology have been built and are operating. The techno-economic model was used to calculate the BESP for 30 years of plant life, considering a 10\% internal rate of return (IRR) and $100 \%$ equity financing. Table 3 shows the base parameters considered in the techno-economic model. The fixed capital investment (FCI) of the process is calculated as the sum of the direct and indirect costs. The total capital investment (TCI) is calculated by adding the cost of land and working capital to the FCI. The direct and indirect costs are calculated as a function of the total installed and direct costs, respectively, as it is shown in Table 4. The operating cost of the process was calculated as sum of the variable operating costs to purchase raw material chemicals and fixed operating costs to pay for employee salaries, overhead, maintenance, and insurance costs [44]. The variable costs were calculated based on the raw material flowrates obtained from Aspen Plus simulation and their relative prices, which are reported in Table S-5 in the supplementary data. Fixed operating costs include labor and maintenance costs, property insurance, and tax. The labor and maintenance costs were estimated to be $1.6 \%$ [45] and 3.0\% of the TCI, respectively, and the property insurance and taxes were collectively estimated to be $0.7 \%$ of the FCI [3].

The revenues generated by the process come from the sale of the electricity and digestate (solid residues from the AD). A digestate selling price of $10.4 \$$ /ton was assumed in this study for the year 2012 [44]. The price of the digestate is dependent on the demand in the local market for fertilizer. Therefore, it may vary throughout the year. A sensitivity analysis was performed in 
Section 3.4.1 on the digestate selling price to understand its impact on the economics of the process.

The capital costs associated with the anaerobic digesters, pneumapress filter, boiler, turbogenerator, etc., were scaled according to vendor quotes reported in Table 5. The prices shown in the table are for packages that contain several pieces of equipment, including heat exchangers, flash drums, pumps, etc. The capital costs are later scaled based on their relative scales and scaling exponents using the equation shown in Table 5. In cases where the capital costs were not available, the module-costing technique and corresponding relationships published by Turton et al. [43] were used. Subsequently, chemical engineering plant cost index was used to update the capital costs for 2012-dollar value.

<Table 3. Parameters of the techno-economic model [46].>

<Table 4. Economic model parameters for calculation of direct and indirect costs [3].>

$<$ Table 5. Capital costs quoted by vendors [3]. Scaling

$$
\text { equation: } \operatorname{Cost}_{\text {New }}=\operatorname{Cost}_{\text {base }}\left(\frac{\text { Scale }_{\text {New }}}{\text { Scale }_{\text {base }}}\right)^{n} .>
$$

\section{Results and discussion}

\subsection{Material and energy balance}

The simulation results were used to obtain the energy and material balances for the process. Table 6 shows the results for the main input/output streams of the process. A detailed material and energy balance for the process is provided in Table S-2-4 in the supplementary data. The turbogenerators produce $35,760 \mathrm{~kW}$ power, of which approximately $7,310 \mathrm{~kW}$ is consumed by the process. Fig. 2 shows the distribution of plant electricity utilization by process 
area. The main energy consuming area is the anaerobic digestion unit, which requires approximately $14 \%$ of the total electricity produced for the agitation of digesters and the air compressor used for pneumatic filter separation of solids and liquids. About $4 \%$ of the electricity produced is consumed by the utilities unit in order to provide the necessary energy for the production of chilled and cooling water. Approximately $95 \%$ of the cooling demands of the process is for the condensation of outlet vapors from the turbines, while the remaining $5 \%$ is for condensing the refrigerant used in the chilled water production process. The boiler/turbogenerator unit consumes approximately $2 \%$ of the total electricity produced in order to meet the energy demands of the pumps and blowers in the unit. A key advantage of the process is that it is self-sufficient in terms of energy requirements, meaning that no fossil fuel is consumed during the production process. This greatly enhances the sustainability of the process and makes it more environmentally friendly compared to other biochemical pathways, such as alcohols production [26],[30],[44],[46]. Results suggest that the economics of AD plant could be further optimized by integrating it within an industrial area to provide power and heat for the consumers and by closing the loop in a circular economy. The AD plant can use the organic wastes of neighboring plants for co-digestion with algae. This would increase the biogas and electricity productions while at the same time reduces the capital costs of waste treatment unit in an industrial region. In addition, heat integration of $\mathrm{AD}$ plant with other plants can reduce the cooling water demands of $\mathrm{AD}$ unit, which consequently increases the exergy and energy efficiency of AD plant.

<Table 6. Results of simulation for the main input/output streams of the process.>

<Fig.2. Plant electricity distribution between process units.> 


\subsection{Capital and investment costs}

The total investment cost of the process was calculated using the methodology described in Section 2.4. Table 7 shows the calculated values for the total installed equipment cost, total investment costs, and the fixed and operating costs. The fixed capital investment (FCI) and total capital investment (TCI) were calculated to be 52.5 and 105.6 million dollars, respectively. The boiler/turbogenerator unit had the highest capital costs ( $\$ 30$ million) of all units. The capital costs of the anaerobic digestion and utilities units were calculated to be 18.5 and 3.9 million dollars, respectively. The feedstock cost was calculated to be 27.2 million dollars per year, which is approximately $94 \%$ of the total variable operating costs, and $85 \%$ of the total operating costs (the sum of the variable and fixed costs). This points to the huge potential for improving the economics of the process by reducing the cost of cultivating the seaweed. Mass cultivation and advanced artificial seaweed cultivation can further reduce the cultivation cost of seaweed. The extent of the impact caused by variations in the cost of seaweed on the economics of the process is assessed in the sensitivity analysis of the economic parameters in Section 3.4.1.

< Table 7. Plant cost worksheet for total capital investment, fixed and variable operating costs, and byproduct revenues.>

\subsection{Breakeven electricity selling price}

The BESP of the process was calculated using the developed discounted cash flow analysis, and found to be $18.81 \propto / \mathrm{kWh}$. Fig. 3 shows the cost contribution details from each process unit to the calculated BESP. The purchase of raw seaweed has the highest contribution to the calculated BESP at $11.95 \phi / \mathrm{kWh}$. The boiler/turbogenerator unit has the second highest contribution at $4.72 ф / \mathrm{kWh}$. It also has the highest capital and fixed costs contribution compared to the other units. Its main capital cost is from the purchase of the boiler, while its main operating 
costs are from the purchase of FGD chemicals and solids disposal. The anaerobic digestion unit has a contribution of $1.44 \phi / \mathrm{kWh}$ with some positive revenue from selling the digestate as fertilizer. The utilities unit has the smallest contribution at $0.7 \varnothing / \mathrm{kWh}$ to the BESP.

<Fig. 3. Cost contribution details from each process area to the BESP.>

The calculated BESP is comparable to the average retail price of electricity (ARPE) in the United States. According to Energy Information Administration (EIA), the ARPE was approximately $12.03 \phi / \mathrm{kWh}$ for the residential sector in 2012 [47]. However, the ARPE varies considerably between states depending on the source of energy used for electricity production. In 2012, the ARPE varied between a minimum of $8.67 \not / \mathrm{kWh}$ in Louisiana and maximum of 36.87 $\notin / \mathrm{kWh}$ in Hawaii. Some of the states that have access to seawater for seaweed cultivation and an ARPE similar to the BESP calculated in this study include the states of New York, New Jersey, Connecticut, Maine, Massachusetts, Vermont, Delaware, California, Alaska, and Hawaii, with ARPEs of $18.35,15.16,17.82,14.76,14.37,18.13,14.51,14.41,17.78,36.87 \phi / \mathrm{kWh}$, respectively. If seaweed were to be cultivated at a large scale in these states, it would provide a sustainable source of biomass for electricity production. This would be especially advantageous for the State of Hawaii because it has the highest electricity price and long sea borders for seaweed cultivation. However, further studies are required to assess the impact of seaweed cultivation on the environment, and to select the appropriate type of seaweed to use by taking into account the temperature and the geography of those states.

\subsection{Sensitivity analysis}

It was of interest to quantify the sensitivity of the BESP to several important process and economic parameters. This was performed using a single-point sensitivity analysis on the Aspen or techno-economic model. Each parameter was varied across a range based on minimum and 
maximum values obtained from the literature or assumed through engineering experience. The results are reported in the form of a tornado chart for the economic parameters and the BESP cost breakdown for process parameters.

\subsubsection{Impact of economic parameters}

A sensitivity analysis was performed on the parameters of the techno-economic model to account for the uncertainties in the biomass price, economic parameters, and possible variations in the capital costs of the process. Several parameters were considered in the sensitivity analysis, including the IRR, biomass price, plant life, FCI, and digestate selling price. Fig. 4 shows the impact of variations in each parameter on the BESP. The base value and the amount of variation for each parameter are also shown in Fig. 4. The results show that the biomass price and the IRR have the highest impact on the BESP. The BESP increased to $21.69 \phi / \mathrm{kWh}$ and $24.91 \phi / \mathrm{kWh}$ when the IRR was increased to $15 \%$ and $20 \%$, respectively, which is approximately a $3 \notin / \mathrm{kWh}$ per $5 \%$ increase in the IRR. The BESP changed from its base value of $18.81 \varnothing / \mathrm{kWh}$ to 13.89 $\phi / \mathrm{kWh}$ and $24.44 \phi / \mathrm{kWh}$ when the biomass price was changed from its base value of $68 \$ /$ ton to $40 \$ /$ ton and $100 \$ /$ ton (dry basis), respectively. This is approximately a $5 \phi / \mathrm{kWh}$ per $30 \$ /$ ton variation in the biomass price. The plant life and the FCI had a moderate impact on the BESP. The results show that reducing the plant life from 30 years to 20 years and then 10 years increased the BESP to $19.36 \phi / \mathrm{kWh}$ and $21.62 \phi / \mathrm{kWh}$, respectively. Results show that the BESP is more sensitive to shorter plant life and does not change linearly with plant life. A change of $\pm 25 \%$ in the FCI resulted in a BESP variation from $20.33 \phi / \mathrm{kWh}$ to $17.30 \phi / \mathrm{kWh}$, respectively. The variation in digestate selling price had less than $1 \phi / \mathrm{kWh}$ impact on the BESP and a change between $5 \$ /$ ton and $15 \$ /$ ton in its selling price changed the BESP between $19.42 \phi / \mathrm{kWh}$ and $18.26 \phi / \mathrm{kWh}$, respectively. 
<Fig. 4. Impact of variation in the techno-economic model parameters on the BESP.>

\subsubsection{Impact of anaerobic digestion temperature}

Several studies in the literature (Table 2) showed that brown algae Laminaria japonica was able to be anaerobically digested under both mesophilic and thermophilic conditions. Therefore, it was of interest to assess the impact of the anaerobic digestion temperature on the BESP. The temperature of the anaerobic digester was changed from a base value of $35{ }^{\circ} \mathrm{C}$ to 55 ${ }^{\circ} \mathrm{C}$. This variation in the anaerobic digestion temperature required several process modifications. First, chilled water was no longer required for cooling the reactors, as the temperature difference between the hot and cold streams was enough to use the cooling water to keep the temperature constant at $55{ }^{\circ} \mathrm{C}$. Therefore, the chilled water system could be removed from the process, resulting in a decrease in the TCI from 105.6 to 102.8 million dollars. Second, part of the steam produced in the boiler at $233{ }^{\circ} \mathrm{C}$ and 9.5 atm was extracted and added to the reactor feed stream to reach a $55^{\circ} \mathrm{C}$ anaerobic digestion temperature. Consequently, the net electricity produced by the process decreased from $28,450 \mathrm{~kW}$ to $27,210 \mathrm{~kW}$. The results of the simulation were exported to the techno-economic model and used to calculate the BESP. The overall impact of the temperature change on the BESP is shown in Fig. 5. The BESP changed from the base value of $18.81 \notin / \mathrm{kWh}$ at $35^{\circ} \mathrm{C}$ to $19.59 \phi / \mathrm{kWh}$ at $55^{\circ} \mathrm{C}$. The results show that increasing the anaerobic digestion temperature had a small negative impact on the economics of the process.

<Fig. 5. Impact of anaerobic digestion temperature on the BESP.>

\subsubsection{Impact of hydraulic retention time}

HRT required for anaerobic digestion is defined by the activity and reaction rate of the microorganisms. The lower the activity of microorganism, the longer the HRT needed to reach the maximum yield. Longer HRT generally requires physically larger or a higher number of 
digesters. Therefore, the HRT is an important parameter as it affects the capital costs of the digesters. Consequently, other economic parameters that are functions of capital costs, including working capital, land, and fixed operating costs are changed. In this study, the HRT was changed from its base value of 10 days to $5,15,20,25$, and 30 days to assess the impact on the BESP. Fig. 6 shows the impact of HRT on the BESP. Results show that the capital costs of the process is the main parameter that is effected by the HRT and causes BESP variations. The TCI of the process changed from its base value of 105.6 million dollars for 10 days HRT to 96.2, 116.4, 131.4, 139.1, and 146.7 million dollars for 5, 15, 20, 25, and 30 days HRT, respectively. The BESP was calculated to be $17.27,20.67,23.05,25.12$, and $27.46 \phi / \mathrm{kWh}$ for $5,15,20,25$, and 30 days HRT, respectively. The impact was between 1.5 to $2.0 \phi / \mathrm{kWh}$ for every 5 days of additional anaerobic digestion, which shows the high impact of the HRT on the BESP. It is noteworthy that since sensitivity analysis in this study is a single point sensitivity analyses, the anaerobic digestion yield for all cases was assumed to be $0.265 \mathrm{~m}^{3} / \mathrm{kg}$ as of the base case. However, in reality, higher HRT implies higher anaerobic digestion yields close to $0.30 \mathrm{~m}^{3} / \mathrm{kg}$. Therefore, changes in BESP is expected to be less for higher HRT. Impact of higher methane yields will be further evaluated in section 3.4.5.

<Fig. 6. Impact of hydraulic retention time on the BESP.>

\subsubsection{Impact of solids loading}

Solids loading is an important parameter in anaerobic digestion processes. Generally, higher solids loading improves the anaerobic digestion environment and increases the yield. However, it also increases fresh water consumption, wastewater production, the power requirements for agitation and handling, the energy demand for heating or cooling, and the size 
and capital costs associated with the anaerobic digesters. Therefore, higher solids loading is preferred as long as the performance of the microorganisms are not affected. The impact of the solids loading was assessed by changing it from the base value of $10 \mathrm{wt} \%$ to 5 and $15 \mathrm{wt} \%$. The process simulation was updated for each case and the capital costs were recalculated. The results for the impact of solids loading on the BESP are shown in Fig. 7. The net power output from the process was changed from the base value of $28,450 \mathrm{~kW}$ to $23,400 \mathrm{~kW}$ and $30,310 \mathrm{~kW}$ for $5 \mathrm{wt} \%$ and $15 \mathrm{wt} \%$ solids loading, respectively. The TCI was changed by approximately 10 million dollars from the base value of 105.6 million dollars to 96.2 and 116.4 million dollars for 5 and 15 wt\% solids loading, respectively. Consequently, the BESP of the process was changed from the base value of $18.81 \phi / \mathrm{kWh}$ to 24.87 and $17.17 \phi / \mathrm{kWh}$ for 5 and $15 \mathrm{wt} \%$ solids loading, respectively. Results showed that the BESP is more sensitive to smaller solids loading because more water is required when decreasing the solids loading. In this case, changing from the base case of $10 \mathrm{wt} \%$ to $5 \mathrm{wt} \%$ required the water flow rate to increase by approximately 553 tons/h, while changing from $10 \mathrm{wt} \%$ to $15 \mathrm{wt} \%$ required the water flow rate to be reduced by approximately 184 ton/h.

<Fig. 7. Impact of solids loading on the BESP.>

\subsubsection{Impact of anaerobic digestion yield}

Anaerobic digestion yield is another important parameter that influences the capital and operating costs, the revenues, and thereby, the economics of the process. The anaerobic digestion yield can change because of variations in the operating conditions of the anaerobic digesters, the microbial source, and the chemical composition of the seaweed due to seasonal changes. Seaweed accumulates carbohydrates, such as mannitol and laminaran, during the hot season (spring and summer), and consumes them during cold season (autumn and winter) [15]. An 
anaerobic digestion yield in the range of $0.23-0.30 \mathrm{~m}^{3} / \mathrm{kg} \mathrm{VS}$ has been reported in the literature [19],[20]. The anaerobic digestion yield was changed from the base value of $0.265 \mathrm{~m}^{3} / \mathrm{kg}$ VS to $0.23 \mathrm{~m}^{3} / \mathrm{kg}$ VS and $0.30 \mathrm{~m}^{3} / \mathrm{kg}$ VS in order to assess the impact of these changes on the BESP. The process simulation was updated for each case and the results were used to recalculate the capital and operating costs in the techno-economic model. The TCI was changed from the base value of 105.6 million dollars to 102.9 and 107.5 million dollars for a methane yield of 0.23 and $0.30 \mathrm{~m}^{3} / \mathrm{kg}$ VS, respectively. The TCI of the process slightly increases with increased anaerobic digestion yield. This is due to the larger equipment size required to handle the larger biogas and steam flow rates. Higher biogas production results in increased steam and electricity production. The net electricity produced by the process changed from the base value of $28,450 \mathrm{~kW}$ to 24,670 and $32,290 \mathrm{~kW}$ for a methane yield of 0.23 and $0.30 \mathrm{~m}^{3} / \mathrm{kg} \mathrm{VS}$, respectively. A lower methane yield leads to more solid residues in the process, thereby increasing revenues from selling the digestate. The results show that the revenues from the sale of digestate changed from the base value of 2.7 million dollars per year to 3.1 and 2.3 million dollars per year for a methane yield of 0.23 and $0.30 \mathrm{~m}^{3} / \mathrm{kg} \mathrm{VS}$, respectively. The overall impact of the anaerobic digestion yield on the BESP was approximately $2 \notin / \mathrm{kWh}$, as shown in Fig. 8 . The BESP of the process changed from the base value of $18.81 \phi / \mathrm{kWh}$ to 21.17 and $16.94 \phi / \mathrm{kWh}$ for a methane yield of 0.23 and 0.30 $\mathrm{m}^{3} / \mathrm{kg}$ VS, respectively.

<Fig. 8. Impact of anaerobic digestion yield on the BESP.>

\section{Conclusion}

In this study, the economics of electricity production from brown algae through $\mathrm{AD}$ were evaluated. The results show that the process consumes approximately $20 \%$ of the electricity produced to meet its energy demands. Therefore, the process is self-sufficient in terms of its 
energy requirements, and does not require fossil fuels, thereby greatly enhancing the sustainability of the production process. The main energy-consuming unit was identified to be the anaerobic digestion unit, which required chilled water for cooling, and power for agitation and solid/liquid separation. A BESP of $18.81 ф / \mathrm{kWh}$ was calculated and found to be comparable to the current electricity selling price in several states in the United States that have the potential for seaweed cultivation. Therefore, seaweed can provide a sustainable source of biomass for electricity production at a competitive price if it is cultivated at large scale in those states. The results also show that the cost of seaweed is the main contributor to the calculated BESP, and indicates a promising potential reduction in the BESP by lowering the cost of seaweed cultivation. Technological advancement in artificial seaweed mass cultivation must be further developed in order for seaweed based bio-fuel and energy production to succeed. In addition, the sensitivity analysis showed that, in order of magnitude, solids loading, anaerobic digestion yield, and time have the highest impact on the BESP, while the anaerobic digestion temperature did not significantly affect the economics of the process. Therefore, identifying and developing microorganisms that can handle higher solids loading while simultaneously providing a higher anaerobic digestion yield can effectively enhance the process economics.

\section{Acknowledgment}

This work was supported by the Ministry of Oceans and Fisheries, Republic of Korea. Dr. Christopher Saffron's contribution to this project was supported by the USDA National Institute of Food and Agriculture (Hatch project MICL02289) and Michigan State AgBioResearch. This paper was presented at American Institute of Chemical Engineers (AICHE 2015) Annual 
Meeting held in Salt Lake City, Utah and was identified as the best presentation in the session "Sustainable Electricity: Generation and Storage". 


\section{References}

[1]. McHugh DJ. A guide to the seaweed industry. FAO fisheries technical paper 441, Food and Agriculture Organization of the United Nations (FAO), 2003.

<http://www.fao.org/docrep/006/y4765e/y4765e00.HTM>

[2].FAO (Food and Agriculture Organization of the United Nations). Renewable Biological Systems for Alternative Sustainable Energy Production (FAO Agricultural Services Bulletin-128), 1997. <http://www.fao.org/docrep/w7241e/w7241e00.htm\#Contents>

[3]. Humbird D, Davis R, Tao L, Kinchin C, Hsu D, Aden A, et al. Process design and economics for biochemical conversion of lignocellulosic biomass to ethanol, National Renewable Energy Laboratory, NREL/TP-5100-47764, Golden, Co, USA, 2011. <http://www.nrel.gov/biomass/pdfs/47764.pdf>

[4]. Aden A, Ruth M, Ibsen K, Jechura J, Neeves K, Sheehan J, et al. Lignocellulosic biomass to ethanol process design and economics utilizing cocurrent dilute acid prehydrolysis and enzymatic hydrolysis for corn stover. Technical Report No. National Renewable Energy Laboratory: NREL/TP-510e32438; Golden, Co. Available from: 2002. http://www1.eere.energy.gov/bioenergy/pdfs/32438.pdf.

[5]. Rodriguez C, Alaswad A, Mooney J, Prescott T, Olabi AG. Review Pre-treatment techniques used for anaerobic digestion of algae. Fuel Process. Technol. 2015;138:765-779.

[6]. Song M, Pham HD, Seon J, Woo HC. Overview of anaerobic digestion process for biofuels production from marine macroalgae: A developmental perspective on brown algae. Korean J. Chem. Eng. 2015;32(4):567-575. 
[7]. Miura T, Kita A, Okamura Y, Aki T, Matsumura Y, Tajima T, Kato J, Nakashimada Y. Evaluation of marine sediments as microbial sources for methane production from brown algae under high salinity. Bioresour. Technol. 2014;169:362-366.

[8]. Miura T, Kita A, Okamura Y, Aki T, Matsumura Y, Tajima T, Kato J, Nakashimada Y. Improved methane production from brown algae under high salinity by fed-batch acclimation. Bioresour. Technol. 2015;187:275-281.

[9]. Tedesco S, Benyounis KY, Olabi AG. Mechanical pretreatment effects on seaweed-derived biogas production in co-digestion with sludge in Ireland. Energy 2013;61:27-33.

[10]. Sharma N, Pellizzi G. Anaerobic biotechnology and developing countries-I. technical status. Energy Convers Manage 1991;32:447-469.

[11]. Binxin Wu. Integration of mixing, heat transfer, and biochemical reaction kinetics in anaerobic methane fermentation. Biotechnol. Bioeng. 2012;109(11):2864-2874.

[12]. Matsui TA, Koike T, Saiganji Y, Saito A. Methane Fermentation of Seaweed Biomass. American Institute of Chemical Engineers Conference - Session 412 - Sustainable Nonfuel Products/Production Systems from Biomass Resources. San Francisco: Tokyo Gas Co. Ltd, 2006.

[13]. Vergara-Fernandez A, Vargas G, Alarcon N, Velasco A. Evaluation of marine algae as a source of biogas in a two-stage anaerobic reactor system Biomass Bioenergy, 2008;32:338344.

[14]. Akunna JC, Hierholtzer A. Co-digestion of terrestrial plant biomass with marine macroalgae for biogas production. Biomass Bioenergy 2016;93:137-143. 
[15]. Sarker S, Møller HB, Bruhn A. Influence of variable feeding on mesophilic and thermophilic co-digestion of Laminaria digitata and cattle manure. Energy Convers manage 2014;87:513-520.

[16]. Chynoweth DP. Review of biomethane from Marine Biomass. History, results and conclusions of the US Marine Biomass Energy Program (1968-1990). 2002. 〈http://abe.ufl.edu/chyn/download/Publications_DC/Reports/marinefinal_FT.pdf>

[17]. Reith JH, Deurwaarder EP, Hemmes K, Curvers A, Kamermans P, Brandenburg W, et al. BIO-OFFSHORE: Grootschalige teelt can zeewieren in combinatie met offshore windparken in de Nordzee. Energy Commission of the Netherlands (ECN). Scientific report C-05-008, 2005. 〈http://www.ecn.nl/docs/library/report/2005/c05008.pdf>

[18]. Roesijadi G, Jones SB, Snowden-Swan LJ, Zhu Y. Seaweed as a biomass feedstock: a preliminary analysis. Pacific Northwest National Laboratory. PNNL-19944, 2010. 〈http://www.pnl.gov/main/publications/external/technical_reports/pnnl-19944.pdf〉

[19]. Chynoweth DP, Owens JM, Legrand R. Renewable methane from anaerobic digestion of biomass. Renewable Energy 2001;22:1-8.

[20]. Gunaseelan, VN. Anaerobic digestion of biomass for methane production: A review. Biomass Bioenergy 1997;13(1-2):83-114.

[21]. Bruton T, Lyons H, Lerat Y, Stanley M, Rasmussen MB. A review of the potential of marine algae as a source of biofuel in Ireland. Dublin, Ireland, Sustainable Energy Ireland. 2009. <http://www.fao.org/uploads/media/0902_SEI_-

_A_Review_of_the_Potential_of_Marine_Algae.pdf>

[22]. National Aeronautics and Space Administration (NASA), Technology readiness level, 2015. 〈http://esto.nasa.gov/files/trl_definitions.pdf> 
[23]. FAO (Food and Agriculture Organization of the United Nations), Fisheries and Aquaculture statistics, 2013.

$<$ http://www.fao.org/figis/servlet/SQServlet?file=/work/FIGIS/prod/webapps/figis/temp/hqp _4573574769364172729.xml\&outtype=html>

[24]. FAO, Yellow Sea Fisheries Research Institute for the Training and Demonstration Course on Laminaria Seafarming. Culture of Kelp (Laminaria japonica) in China. Training Manual 89/5, Food and Agriculture Organization of the United Nations (FAO), 1989. < http://www.fao.org/docrep/field/003/ab724e/AB724E00.htm\#TOC>

[25]. Okoli C, Adams T, Brigljevic B, Liu J. Design and economic analysis of a macroalgaeto-butanol process via a thermochemical route. Energy Convers manage 2016;123:410-422.

[26]. Fasahati P, Woo HC, Liu J. Industrial-scale bioethanol production from brown algae: Effects of pretreatment processes on plant economics. Appl. Energy 2015;139:175-187.

[27]. Wright M, Satrio JA, Brown RC. Techno-Economic Analysis of Biomass Fast Pyrolysis to Transportation Fuels. NREL/TP-6A20-46586, 2010. <http://www.nrel.gov/docs/fy11osti/46586.pdf>

[28]. Qureshi N, Saha BC, Cotta MA, Singh V. An economic evaluation of biological conversion of wheat straw to butanol: a biofuel. Energy Convers Manage 2013;65:456-62. http://dx.doi.org/10.1016/j.enconman.2012.09.015.

[29]. Hess JR, Kenney KL, Ovard LP, Searcy EM, Wright CT. Uniform-Format Solid Feedstock Supply System: A Commodity-Scale Design to Produce an Infrastructure Compatible Bulk Solid from Lignocellulosic Biomass, Section 3: Pioneer Uniform Feedstock Supply System. Report No. INL/EXT-08-14752. Idaho Falls, ID: Idaho National Laboratory, 2009. 
[30]. Fasahati P, Liu J. Impact of volatile fatty acid recovery on economics of ethanol production from brown algae via mixed alcohol synthesis. Chem. Eng. Res. Des. 2015;98:107-122.

[31]. Pham TN, Nam WJ, Jeon YJ, Yoon HH. Volatile fatty acids production from marine macroalgae by anaerobic fermentation. Bioresour. Technol. 2012;124:500-503.

[32]. Chang H, Kim N, Kang J, Jeong C. Biomass-derived Volatile Fatty Acid Platform for Fuels and Chemicals. Biotechnol. Bioprocess Eng. 2010;15:1-10.

[33]. Rajendran K, Kankanala HR, Lundin M, Taherzadeh MJ. A novel process simulation model (PSM) for anaerobic digestion using Aspen Plus. Bioresour. Technol. 2014;168:7-13.

[34]. Wang Q, Kuninobu M, Ogawa HI, Kato Y. Degradation of volatile fatty acids in highly efficient anaerobic digestion. Biomass Bioenerg. 1999;16:407-416.

[35]. Murphy JD, Thamsiriroj T. Fundamental science and engineering of the anaerobic digestion process for biogas production, in: A. Wellinger, J.P. Murphy, D. Baxter (Eds.), The Biogas Handbook, Elsevier; 2013, p. 104-130.

[36]. Deublein D, Steinhauser A. Biogas from Waste and Renewable Resources: An Introduction, John Wiley \& Sons, 2011.

[37]. Chynoweth DP, Turick CE, Owens JM, Jerger DE, Peck MW. Biochemical methane potential of biomass and waste feedstocks. Biomass Bioenergy 1993;5:95-111.

[38]. Chynoweth DP, Fannin KF, Srivastava VJ. Biological gasification of marine algae. Seaweed Cultivation for Renewable Resources. K. B. a. P. Benson. New York, Elsevier, 1987, p.285-303.

[39]. Troiano RA, Wise DL, Augenstein DC, Kispert RG, Cooney CL. Fuel gas production by anaerobic digestion of kelp. Resour. Recovery Conserv. 1976;2:171-176. 
[40]. Hanssen JF, Indergaard M, Ostgaard K, Baevre A, Pedersen TA, Jensen A. Anaerobic digestion of Laminaria spp. and Ascophyllum nodosum and application of end products. Biomass 1987;14:1-13.

[41]. Chynoweth DP, Srivastava VJ. Methane production from marine biomass. Paper presented at International Symposium on Biogas, Microalgoe and Livestock Wastes, Taipei. Taiwan. Institute of Gas Technology. IL. 15-17, 1980.

[42]. Environmental protection agency (EPA), Air pollution control technology fact sheet, 2014. 〈http://www3.epa.gov/ttncatc1/dir1/ffdg.pdf>

[43]. Turton R, Bailie RC, Whiting WB, Shaeiwitz JA. Analysis, synthesis and design of chemical processes, second ed., New Jersey: Prentice Hall; 2003.

[44]. Fasahati P, Liu J. Application of MixAlco® processes for mixed alcohol production from brown algae: Economic, energy, and carbon footprint assessments. Fuel Process. Technol. 2016;144:262-273.

[45]. Perales AL, Valle CR, Ollero P, Gómez-Barea A. Technoeconomic assessment of ethanol production via thermochemical conversion of biomass by entrained flow gasification. Energy 2011;36:4097-4108.

[46]. Fasahati P, Liu J. Economic, energy, and environmental impacts of alcohol dehydration technology on biofuel production from brown algae. Energy 2015;93:2321-2336.

[47]. U.S. Energy Information Administration. 2012. < http://www.eia.gov/electricity/monthly/>. 
Table 1. Reported operating conditions and methane yield for anaerobic digestion of several type of brown algae.

\begin{tabular}{lllll}
\hline Brown algae type & $\begin{array}{l}\mathbf{C H}_{4} \text { yield } \\
\left(\mathbf{m}^{3} / \mathbf{k g} \text { VS }\right)\end{array}$ & Temperature $\left({ }^{\circ} \mathbf{C}\right)$ & Time (days) & Ref. \\
& 0.18 & 35 & & \\
\hline L. japonica & $0.14 \sim 0.17$ & 37 & $6 \sim 20$ & {$[8]$} \\
L. Digitata & 0.297 & 55 & 21 & {$[9]$} \\
L. japonica & $0.25 \sim 0.28$ & 35 & $17 \sim 28$ & {$[12]$} \\
L. japonica & $0.24 \sim 0.30$ & 35 & $14 \sim 46$ & {$[37]$} \\
L. japonica & $0.205 \sim 0.220$ & 37 & $9 \sim 30$ & {$[38]$} \\
L. saccharina* & 0.230 & 35 & 25 & {$[39]$} \\
L. saccharina* & 0.110 & 35 & 24 & {$[40]$} \\
Ascophyllum nodosum* & 0.280 & 35 & 24 & {$[40]$} \\
L. hyperborea* & $0.277-0.310$ & 38 & 24 & {$[40]$} \\
Macrocystis pyrifera (giant kelp) & & 18 & {$[41]$} \\
\hline
\end{tabular}

*. Reported in [16]. 
Table 2. Stoichiometric anaerobic digestion reactions obtained from literature [30].

\begin{tabular}{|c|c|c|c|}
\hline Component & Rea & action & Ref. \\
\hline Glucose & (1) & $5 \mathrm{C}_{6} \mathrm{H}_{12} \mathrm{O}_{6}+4 \mathrm{H}_{2} \mathrm{O} \rightarrow 6 \mathrm{C}_{2} \mathrm{H}_{4} \mathrm{O}_{2}+2 \mathrm{C}_{3} \mathrm{H}_{6} \mathrm{O}_{2}+\mathrm{C}_{4} \mathrm{H}_{8} \mathrm{O}_{2}+8 \mathrm{CO}_{2}+12 \mathrm{H}_{2}$ & {$[31][32]$} \\
\hline $\begin{array}{l}\text { Laminaran \& } \\
\text { cellulose }\end{array}$ & (2) & $5 \mathrm{C}_{6} \mathrm{H}_{10} \mathrm{O}_{5}+9 \mathrm{H}_{2} \mathrm{O} \rightarrow 6 \mathrm{C}_{2} \mathrm{H}_{4} \mathrm{O}_{2}+2 \mathrm{C}_{3} \mathrm{H}_{6} \mathrm{O}_{2}+\mathrm{C}_{4} \mathrm{H}_{8} \mathrm{O}_{2}+8 \mathrm{CO}_{2}+12 \mathrm{H}_{2}$ & \\
\hline Mannitol & (3) & $5 \mathrm{C}_{6} \mathrm{H}_{14} \mathrm{O}_{6}+4 \mathrm{H}_{2} \mathrm{O} \rightarrow 6 \mathrm{C}_{2} \mathrm{H}_{4} \mathrm{O}_{2}+2 \mathrm{C}_{3} \mathrm{H}_{6} \mathrm{O}_{2}+\mathrm{C}_{4} \mathrm{H}_{8} \mathrm{O}_{2}+8 \mathrm{CO}_{2}+17 \mathrm{H}_{2}$ & \\
\hline Alginate & (4) & $\begin{array}{l}5 \mathrm{C}_{6} \mathrm{H}_{8} \mathrm{O}_{6}+12 \mathrm{H}_{2} \mathrm{O} \rightarrow 6 \mathrm{C}_{2} \mathrm{H}_{4} \mathrm{O}_{2}+2 \mathrm{C}_{3} \mathrm{H}_{6} \mathrm{O}_{2}+\mathrm{C}_{4} \mathrm{H}_{8} \mathrm{O}_{2}+8 \mathrm{CO}_{2}+ \\
10 \mathrm{H}_{2}\end{array}$ & \\
\hline Fucose & (5) & $5 \mathrm{C}_{6} \mathrm{H}_{12} \mathrm{O}_{5}+9 \mathrm{H}_{2} \mathrm{O} \rightarrow 6 \mathrm{C}_{2} \mathrm{H}_{4} \mathrm{O}_{2}+2 \mathrm{C}_{3} \mathrm{H}_{6} \mathrm{O}_{2}+\mathrm{C}_{4} \mathrm{H}_{8} \mathrm{O}_{2}+8 \mathrm{CO}_{2}+17 \mathrm{H}_{2}$ & \\
\hline Protein & (6) & $\mathrm{C}_{13} \mathrm{H}_{25} \mathrm{O}_{7} \mathrm{~N}_{3} \mathrm{~S}+6 \mathrm{H}_{2} \mathrm{O} \rightarrow 6.5 \mathrm{CH}_{4}+6.5 \mathrm{CO}_{2}+3 \mathrm{NH}_{3}+\mathrm{H}_{2} \mathrm{~S}$ & {$[33]$} \\
\hline Lipid & (7) & $\mathrm{C}_{18} \mathrm{H}_{34} \mathrm{O}_{2}+8.5 \mathrm{H}_{2} \mathrm{O} \rightarrow 12.75 \mathrm{CH}_{4}+5.25 \mathrm{CO}_{2}$ & [3] \\
\hline Acetic acid & (8) & $\mathrm{CH}_{3} \mathrm{COOH} \rightarrow \mathrm{CH}_{4}+\mathrm{CO}_{2}$ & {$[34]$} \\
\hline Propionic acid & (9) & $4 \mathrm{CH}_{3} \mathrm{CH}_{2} \mathrm{COOH}+2 \mathrm{H}_{2} \mathrm{O} \rightarrow 7 \mathrm{CH}_{4}+5 \mathrm{CO}_{2}$ & {$[34]$} \\
\hline Butyric acid & $(10)$ & $\mathrm{CH}_{3} \mathrm{CH}_{2} \mathrm{CH}_{2} \mathrm{COOH}+2 \mathrm{H}_{2} \mathrm{O} \rightarrow 2 \mathrm{CH}_{4}+2 \mathrm{CO}_{2}+2 \mathrm{H}_{2}$ & {$[34]$} \\
\hline
\end{tabular}


Table 3. Parameters of the techno-economic model [46].

\begin{tabular}{ll}
\hline Parameter & Value \\
\hline Cost basis year & 2012 dollars \\
Plant life and location & 30 years, USA \\
Internal rate of return (IRR). & $10 \%$ \\
Depreciation method (recovery period) & $200 \%$ declining balance (7 years) \\
Tax rate & $35 \%$ per year \\
Working capital* & $5 \%$ of fixed capital investment (FCI) \\
Land $*$ & $6 \%$ of installed cost \\
Salvage value & 0 M\$ $\$$ \\
Construction period & One year \\
Startup period & 3 Month \\
Revenues during start-up & $50 \%$ \\
Variable costs incurred during start-up & $75 \%$ \\
Operating hours per period & $100 \%$ \\
\hline
\end{tabular}

*. Working capital and cost of land are recovered at the end of plant life. 
Table 4. Economic model parameters for calculation of direct and indirect costs [3].

\begin{tabular}{ll}
\hline Direct costs & $\%$ of installed costs \\
Installed costs & $100 \%$ \\
Warehouse & $4 \%$ \\
Site development & $9 \%$ \\
Additional piping & $4.5 \%$ \\
Indirect costs & $\%$ of total direct costs (TDC) \\
Prorateable costs & $10 \%$ \\
Field expenses & $10 \%$ \\
Home office and construction & $20 \%$ \\
Project contingency & $10 \%$ \\
Other costs & $10 \%$ \\
\hline
\end{tabular}


Table 5. Capital costs quoted by vendors [3]. Scaling equation: $\operatorname{Cost}_{\text {New }}=\operatorname{Cost}_{\text {base }}\left(\frac{\text { Scale }_{\text {New }}}{\text { Scale }_{\text {base }}}\right)^{n}$.

\begin{tabular}{|c|c|c|c|c|}
\hline Item & $\begin{array}{c}\text { Scaling exponent } \\
\text { (n) }\end{array}$ & Year & Cost $(\$)$ & $\begin{array}{c}\text { Installation } \\
\text { factor }\end{array}$ \\
\hline Fermentation reactor & 0.56 & 2012 & $6,450,000$ & 1.05 \\
\hline Flash tank & 0.7 & 2009 & 511,000 & 2.0 \\
\hline Pneumapress filter & 0.8 & 2010 & $3,294,700$ & 1.7 \\
\hline Turbine/Generator & 0.6 & 2010 & $9,500,000$ & 1.8 \\
\hline $\begin{array}{l}\text { Hot Process Water Softener } \\
\text { System }\end{array}$ & 0.6 & 2010 & 78,000 & 1.8 \\
\hline Amine Addition Pkg. & 0 & 2010 & 40,000 & 1.8 \\
\hline Deaerator & 0.6 & 2010 & 305,000 & 3 \\
\hline Cooling Tower System & 0.6 & 2010 & $1,375,000$ & 1.5 \\
\hline Chilled Water Package & 0.6 & 2010 & $1,275,750$ & 1.5 \\
\hline Process Water Tank & 0.7 & 2009 & 250,000 & 1.7 \\
\hline Pressure swing adsorption unit* & 0.6 & 2002 & $4,855,471$ & 2.47 \\
\hline
\end{tabular}

\footnotetext{
*. From [49]
} 
Table 7. Plant cost worksheet for total capital investment, fixed and variable operating costs, and byproduct revenues.

\section{Cost $(\$)$}

Fermentation unit

Boiler/Turbogenerator unit

Utilities unit

Total Installed Costs (TIC)

Total Direct Costs (TDC)

Total Indirect Costs

Fixed Capital Investment (FCI)

Land

Working Capital

Total Capital Investment (TCI)

Feedstock (per year)

Other variable operating cost (per year)

Total fixed operating cost (per year)

Digestate selling (per year)
$18,500,000$

$30,000,000$

$3,900,000$

$52,500,000$

$61,000,000$

$36,600,000$

$97,500,000$

$3,100,000$

$4,900,000$

$105,600,000$

$27,200,000$

$1,800,000$

$3,000,000$

$2,700,000$ 
Table 6. Results of simulation for the main input/output streams of the process.

\begin{tabular}{ll}
\hline Stream & Mass flow $(\mathrm{kg} / \mathrm{hr})$ \\
\hline Brown algae $^{*}$ & 62,500 \\
Net electricity to the grid $(\mathrm{kW})$ & 28,450 \\
Digestate & 33,148 \\
Fresh water & 609,250 \\
Waste water & 489,860 \\
Solid waste & 1,030 \\
FGD Lime & 614 \\
Boiler chemicals & 0.0323 \\
Cooling tower chemicals & 1.52 \\
\hline * including 20\% moisture. &
\end{tabular}




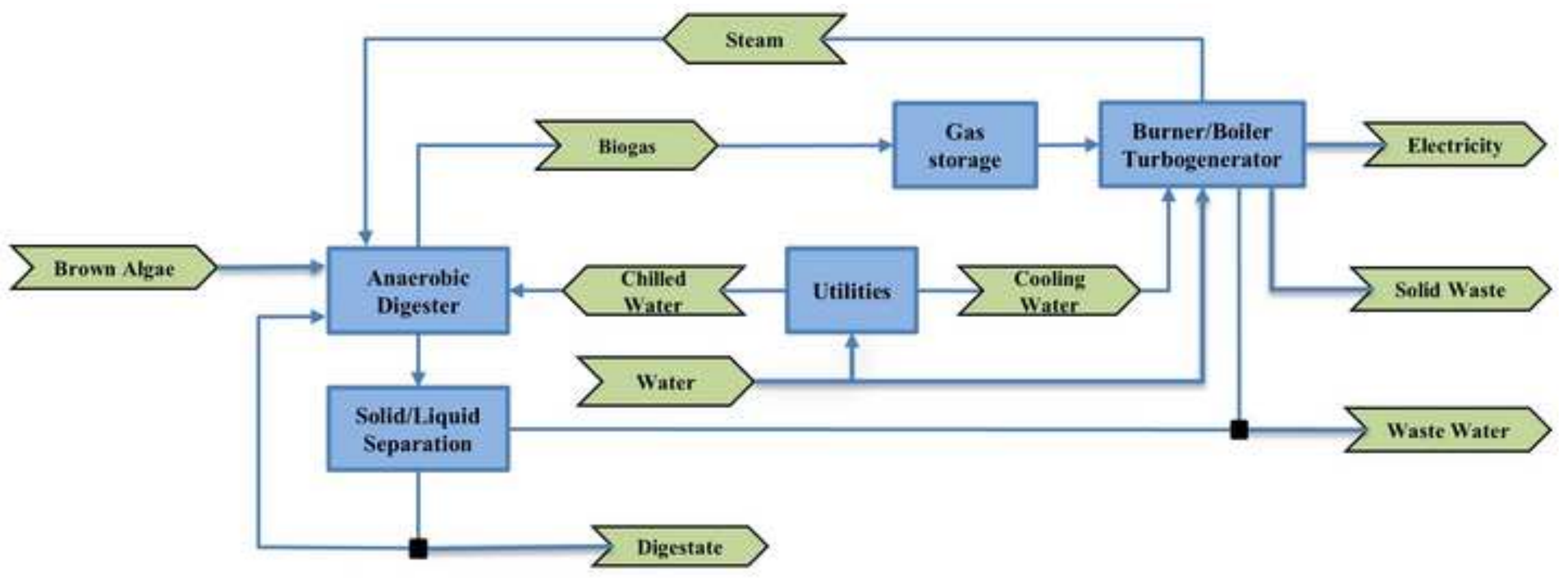




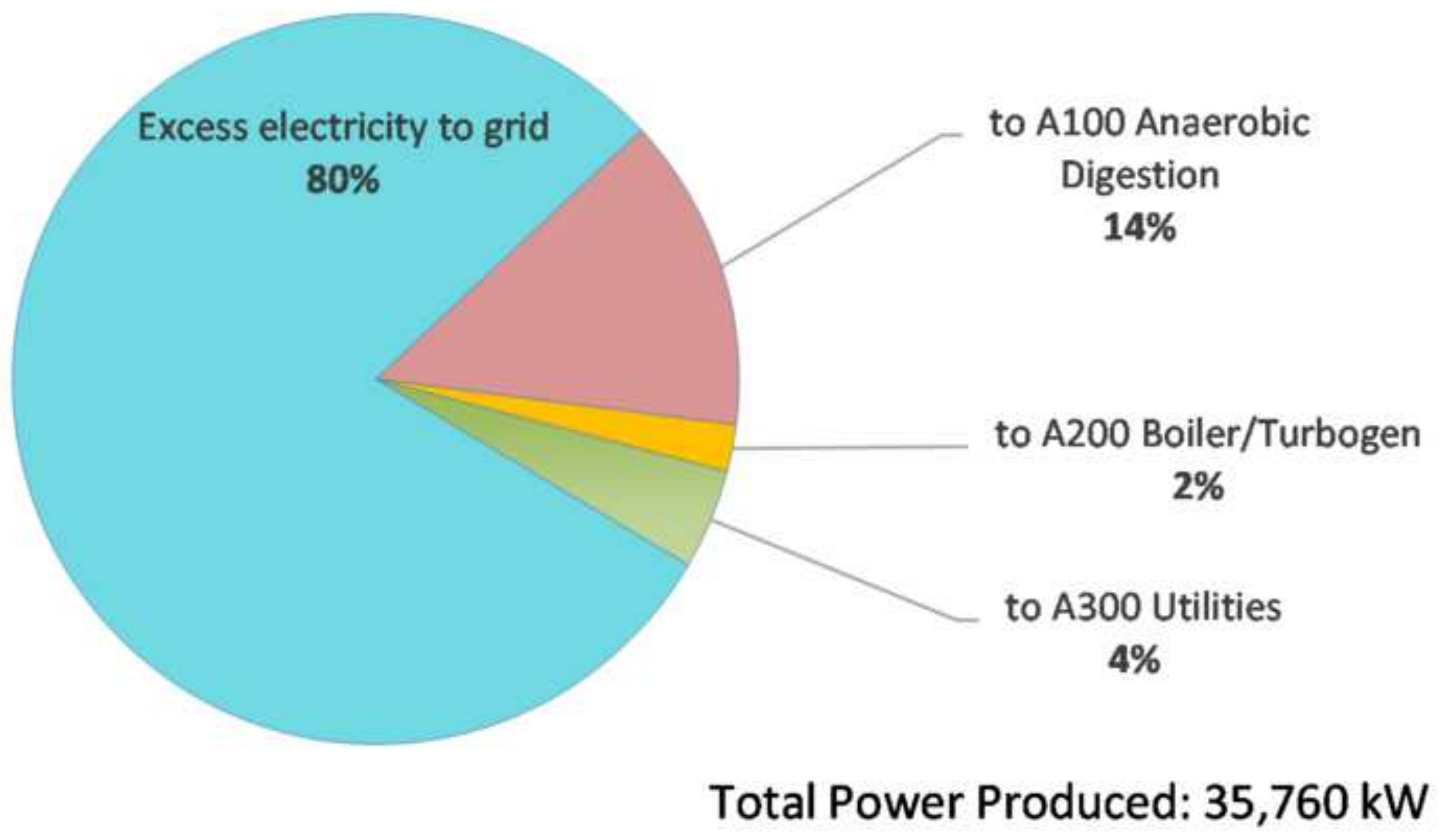


Mapital Recovery Charge Maw Materials

naste Water

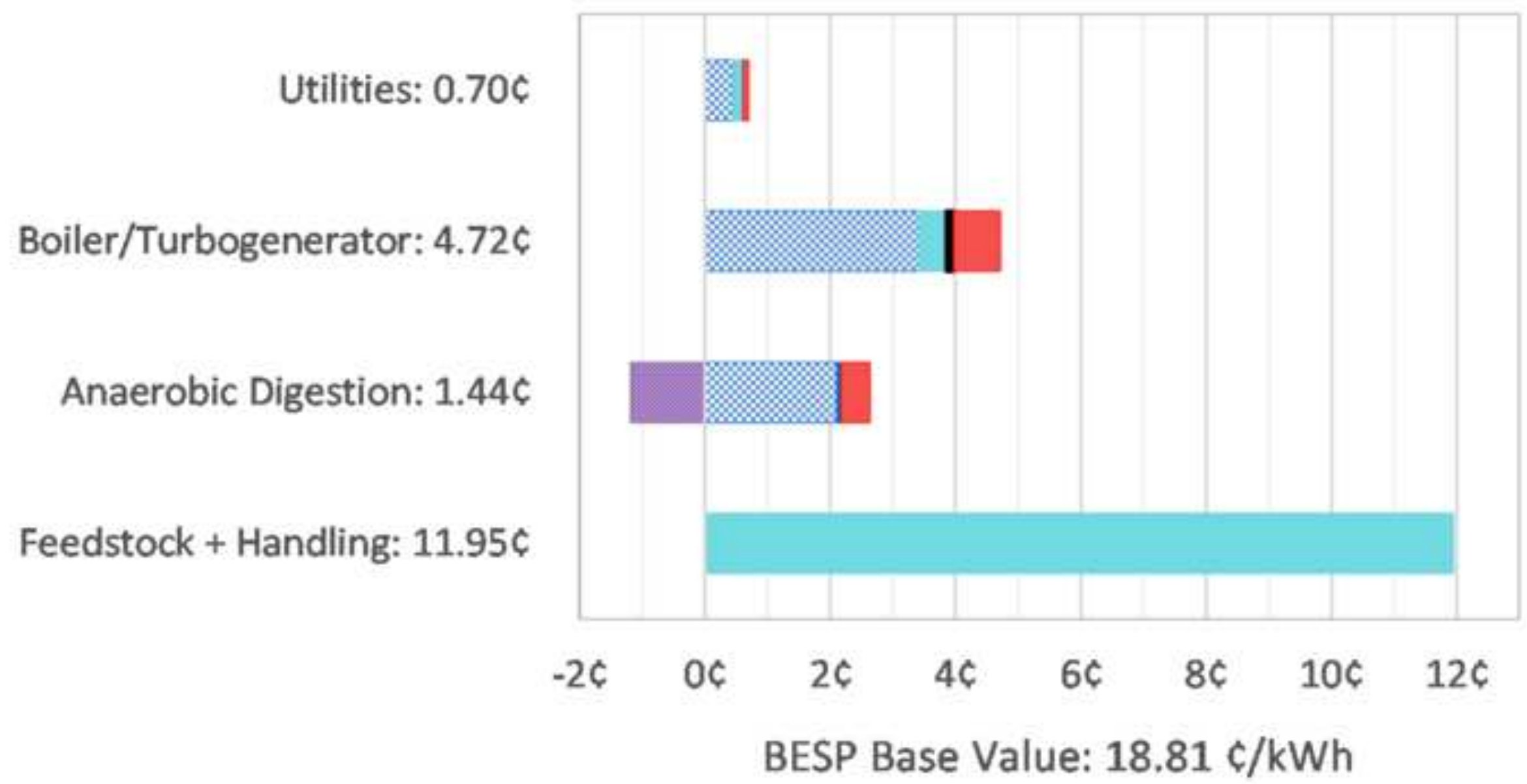

- Ash Disposal

- Fixed Costs

$$
\text { Utilities: } 0.70 c
$$

Eigestate 


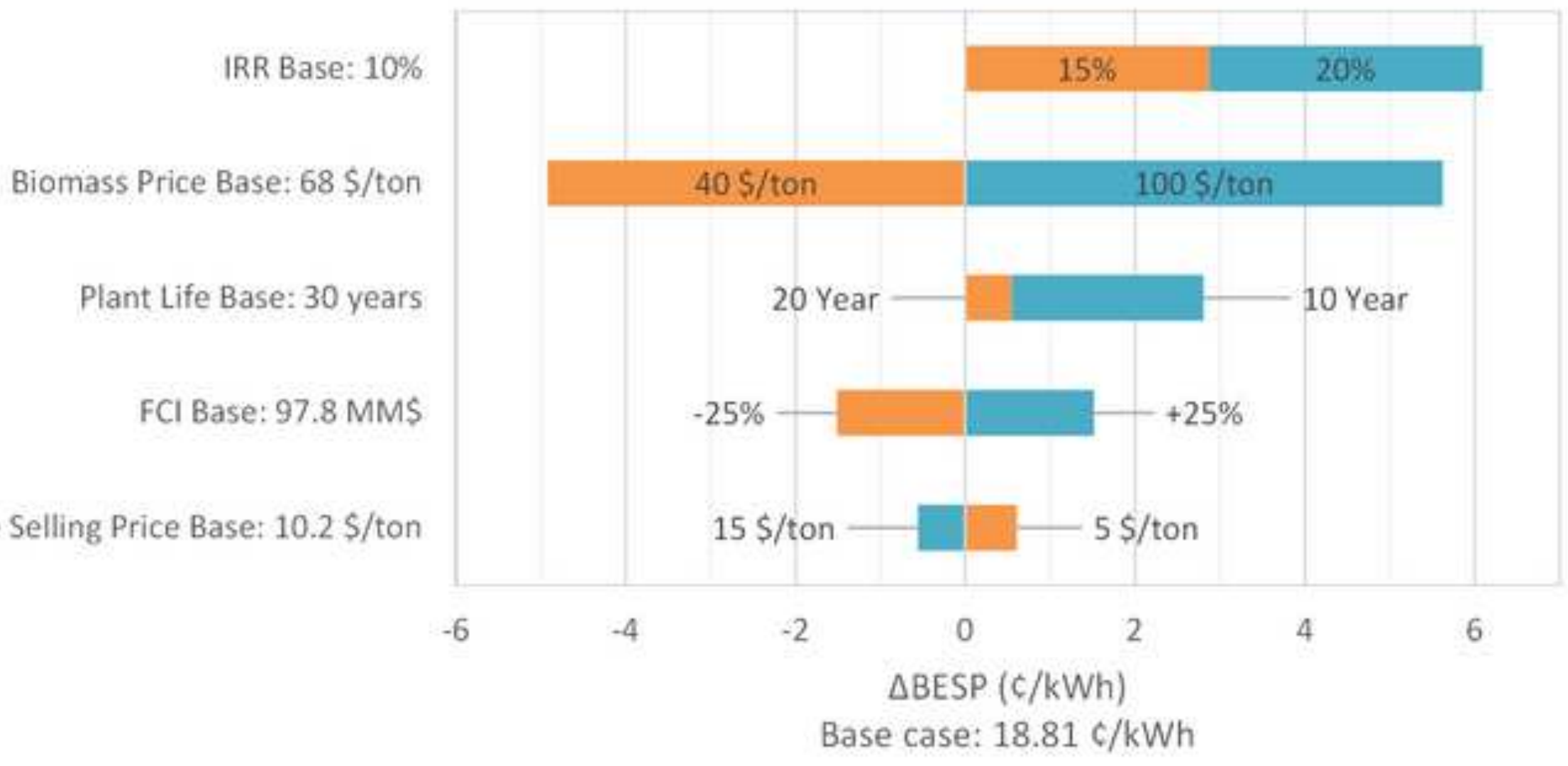

Digestate Selling Price Base: $10.2 \$ /$ ton

Base case: $18.81 \mathrm{c} / \mathrm{kWh}$ 


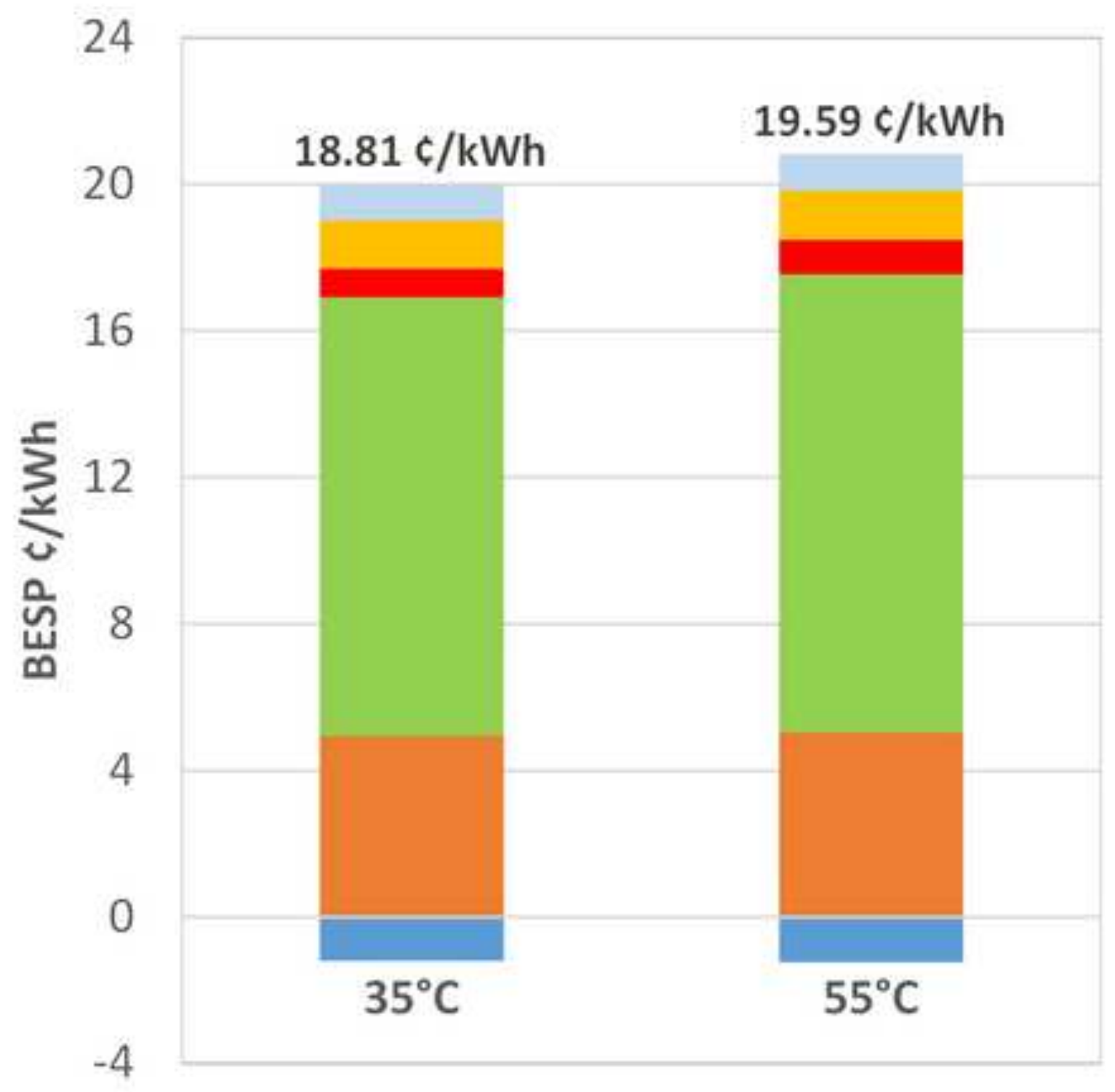

Income Tax

- Fixed Operating Costs

- Other Variable Costs

몸 Feedstock

- Fixed Capital Investment

- Digestate 


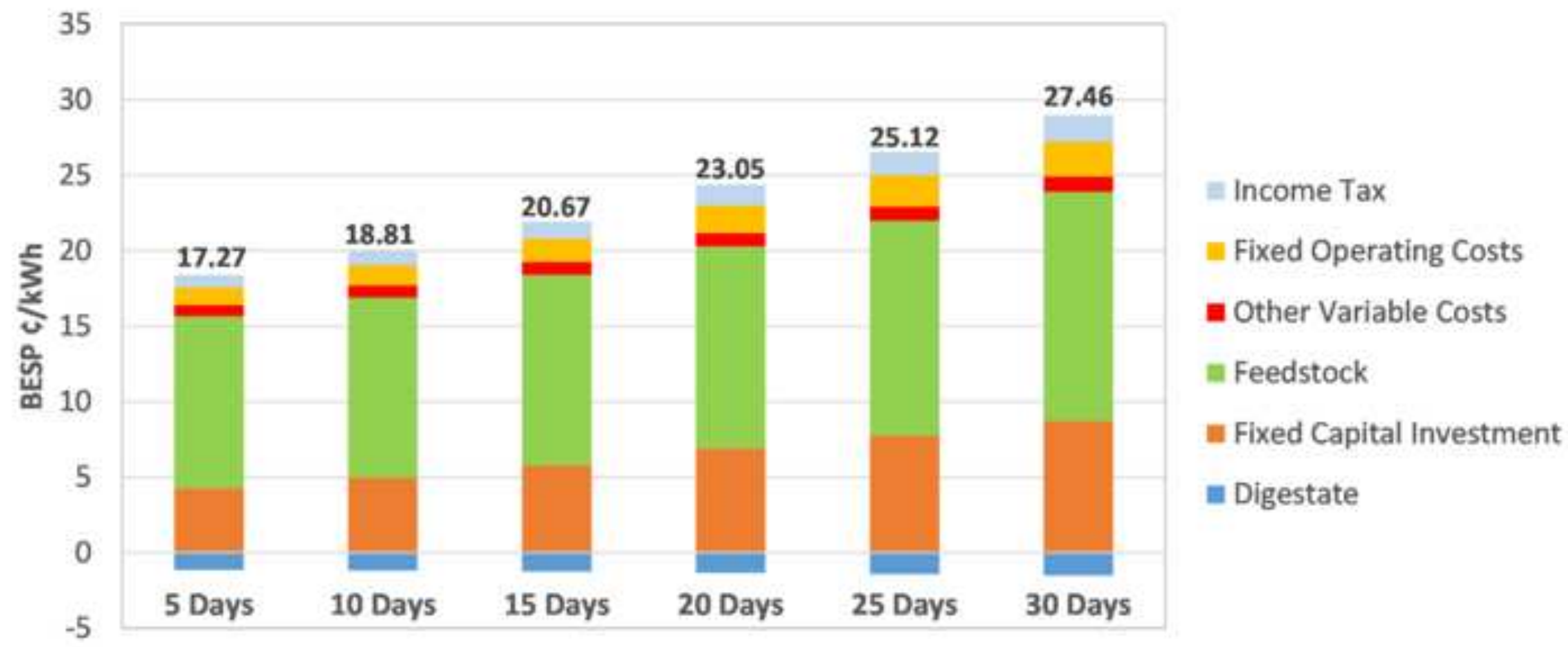




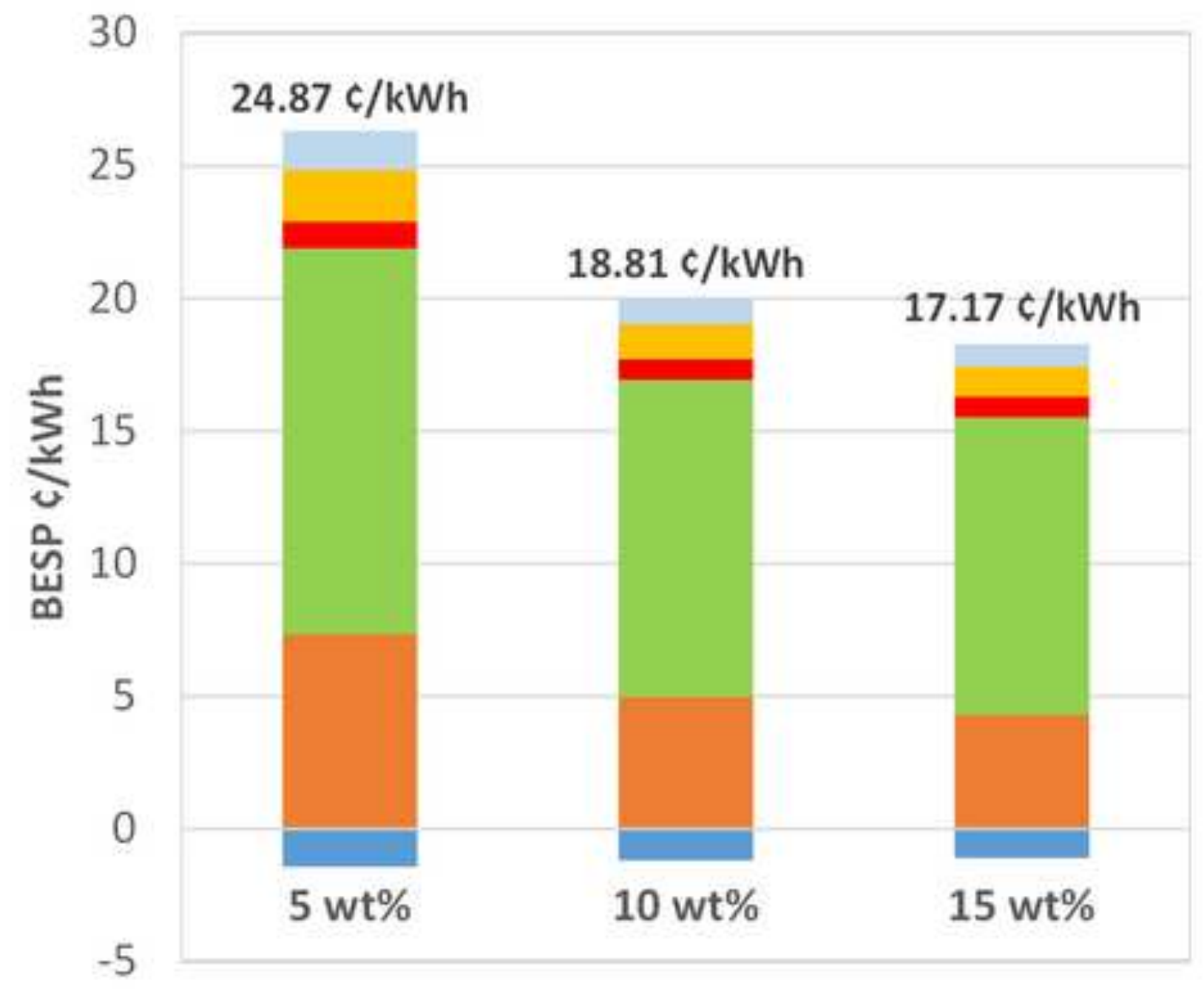

income Tax

Iixed Operating Costs

Other Variable Costs

Feedstock

- Fixed Capital Investment

iㅡ Digestate 


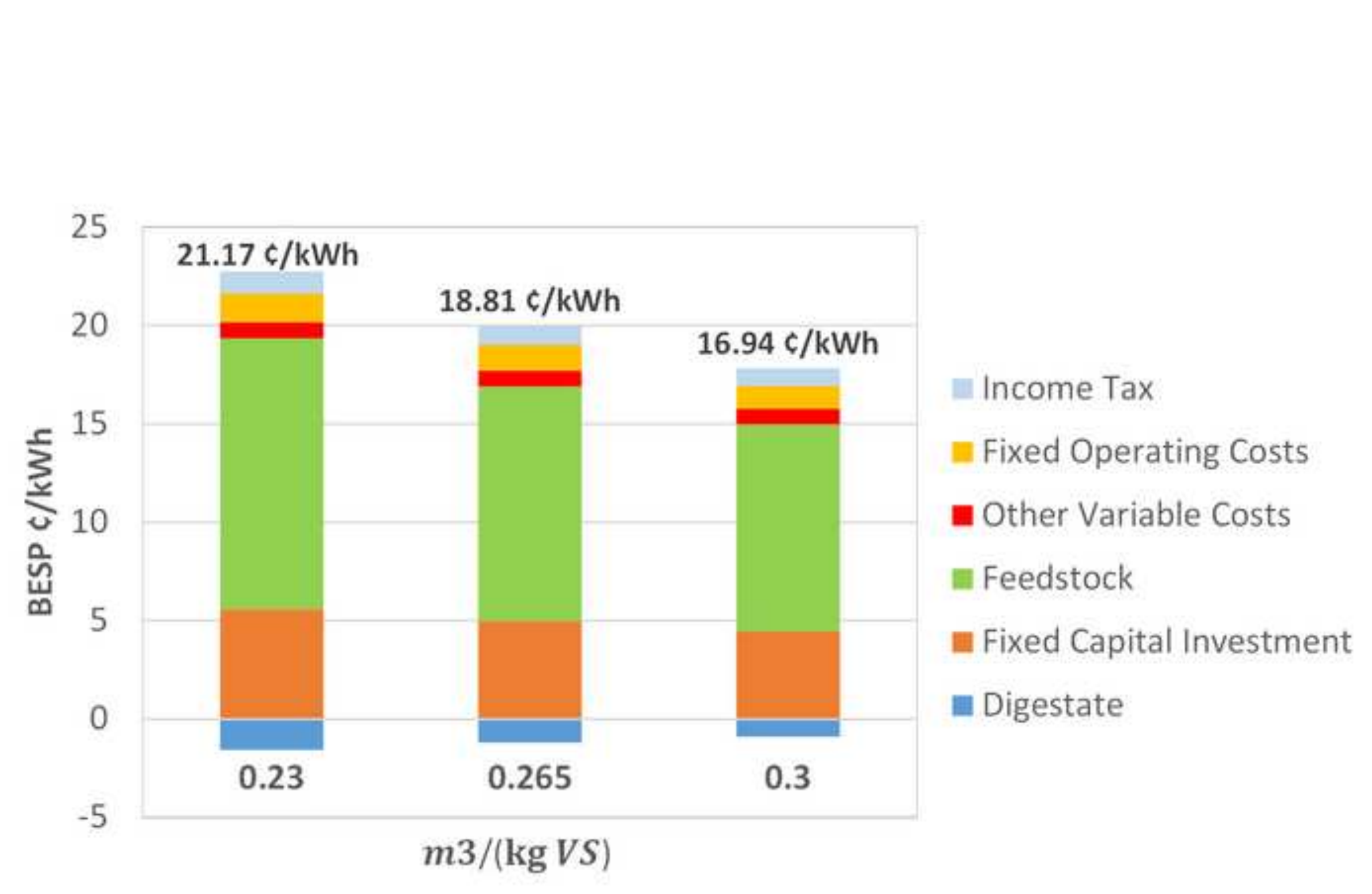

8

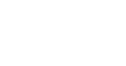


